\title{
The importance of protozoan bacterivory in a subtropical environment (Lobo-Broa Reservoir, SP, Brazil)
}

\author{
Mansano, AS. ${ }^{a *}$, Hisatugo, KF. ${ }^{a}$, Hayashi, LH. ${ }^{a}$ and Regali-Seleghim, MH. ${ }^{a}$ \\ ${ }^{a}$ Departamento de Ecologia e Biologia Evolutiva, Universidade Federal de São Carlos - UFSCar, \\ Rod. Washington Luis, Km 235, CEP 13564-905, São Carlos, SP, Brazil \\ *e-mail: laine_mansano@yahoo.com.br
}

Received: July 31, 2012 - Accepted: April 4, 2013 - Distributed: August 31, 2014

(With 5 figures)

\begin{abstract}
This study evaluated the importance of heterotrophic nanoflagellates (HNF) and ciliates bacterivory in a mesotrophic subtropical environment (Lobo-Broa Reservoir, Brazil) by the quantification of their ingestion rates. The in situ experiments using fluorescently labelled bacteria (FLB) were carried out bimonthly over one year (three surveys in the dry season and three in the rainy one) at the sub-surface of two sampling points that have different trophic degrees. The ingestion rates for both ciliates and HNF were higher in the meso-eutrophic region (point 2) due to the higher water temperatures, which accelerate the metabolism of protozoans and the higher bacteria densities. Concerning total protozoan bacterivory, the HNF had the greatest grazing impact on bacterial community, especially the HNF $<5 \mu \mathrm{m}$. The data showed that HNF grazing, in addition to regulating the bacteria abundance, also induced changes to the bacterial community structure, such as increasing size and numbers of bacterial filaments. The ciliates were also important to the system bacterivory, especially in point 2 , where there were high densities and ingestion rates. The protozoan bottom-up control was more important in the dry season and the top-down control was more important in the rainy season, so, these two forces are equally important to the bacterial abundance regulation in this reservoir in an annual basis.
\end{abstract}

Keywords: grazing, bacteria, nanoflagellates, ciliates, mesotrophic.

\section{A importância da bacterivoria por protozoários em um ambiente subtropical (Reservatório do Lobo-Broa, SP, Brasil)}

\begin{abstract}
Resumo
Este estudo avaliou a importância da bacterivoria por nanoflagelados heterotróficos (NFH) e ciliados em um ambiente subtropical mesotrófico (Reservatório do Lobo-Broa, Brasil) pela quantificação de suas taxas de ingestão. Os experimentos in situ utilizando bactérias marcadas por fluorescência (FLB) foram realizados bimestralmente durante um ano (três estudos no período seco e três no período chuvoso) na superfície de dois pontos de coleta que apresentam graus de trofia diferentes. As taxas de ingestão, tanto para os ciliados quanto para os NHF, foram maiores no ponto 2 (P2) devido provavelmente as maiores temperaturas da água, que aceleram o metabolismo dos protozoários, e as maiores densidades de bactérias. Em relação à bacterivoria total por protozoários, as populações de NFH causaram maior impacto de predação sobre a comunidade bacteriana do reservatório, principalmente os NFH menores que $5 \mu \mathrm{m}$. Os dados indicaram que a predação por NFH, além de regular a abundância de bactérias, provavelmente também induziu modificações na estrutura da comunidade bacteriana, como o aumento do tamanho e da quantidade de filamentos bacterianos. Os ciliados também contribuíram significativamente para a bacterivoria no sistema, principalmente no P2, onde apresentaram altas densidades e taxas de ingestão. O controle bottom-up teve maior importância no período seco e o controle top-down maior importância no período chuvoso, assim, estas duas forças são igualmente importantes na regulação da abundância bacteriana neste reservatório em uma base anual.
\end{abstract}

Palavras-chave: grazing, bactérias, nanoflagelados, ciliados, mesotrófico.

\section{Introduction}

Bacterial community play an important role in the organic matter decomposition, nutrient cycling and as food for organisms of higher trophic levels, thus representing fundamental components in planktonic food webs. The bacterial densities in aquatic systems are controlled by various factors such as nutrient availability (e.g. Pinhassi et al., 2006), predation (e.g. Weinbauer et al., 2007), viral lysis (e.g. Motegi et al., 2009) and temperature (e.g. Apple et al., 2008). However, among these factors, the nutrient availability and predation, known respectively as 
bottom-up and top-down, are the main bacterial controllers in the systems (Wright, 1988).

The main bacterial consumers in aquatic ecosystems are protozoans, especially the small heterotrophic nanoflagellates (e.g. Ichinotsuka et al., 2006) and ciliates (e.g. Zingel et al., 2007), which act as a link to higher predators. Other planktonic organisms, especially rotifers and cladocerans, also influence the bacterial densities through direct consumption or indirectly feeding ciliates and flagellates (e.g. Zöllner et al., 2009). Several studies have recognised that protozoan grazing is an important controlling and modifier factor of bacterial populations and communities, capable of causing direct impacts on their production and biomass, as well as changes on their structure, morphology, physiology, taxonomy (e.g. Corno et al., 2008) and diversity (Bell et al., 2010).

This study aimed to analyse the bacterivory in the LoboBroa Reservoir, a mesotrophic subtropical environment, by quantifying the in situ bacterial ingestion rates by protozoan ciliates and heterotrophic nanoflagellates, in order to evaluate the importance of these populations to the bacterioplanktonic control.

\section{Material and Methods}

\subsection{Study area and sampling}

The Lobo Reservoir (Broa) is located at $770 \mathrm{~m}$ altitude in the central-western region of the São Paulo state, Brazil - latitude $22^{\circ} 15^{\prime} \mathrm{S}$ and longitude $47^{\circ} 49^{\prime} \mathrm{W}$ (see Figure 1). The reservoir has a maximum length of $8 \mathrm{~km}$, volume of $22 \times 10^{6} \mathrm{~m}^{3}$ and average depth of $3 \mathrm{~m}$ (Tundisi et al., 2004). The climate of the area is subtropical mesothermic - Cwa, according to Köppen, with a dry winter (from April to September) and wet summer (from October to March). In general, the reservoir is considered mesotrophic, but it can be divided into two longitudinal compartments: a meso-eutrophic, in the upper part, with high concentrations of macrophytes and rich in dissolved nutrients from the inflow of the Itaqueri River; and an oligo-mesotrophic, in the lower part (near the dam), which is deeper (Motheo, 2005). Due to the spatial heterogeneity, two sampling points (see Figure 1) were selected in this work: the point 1 (P1) is located near the dam and the point 2 (P2) is positioned near the mouth of the Itaqueri River. The samplings and the in situ grazing experiments were conducted bimonthly, at

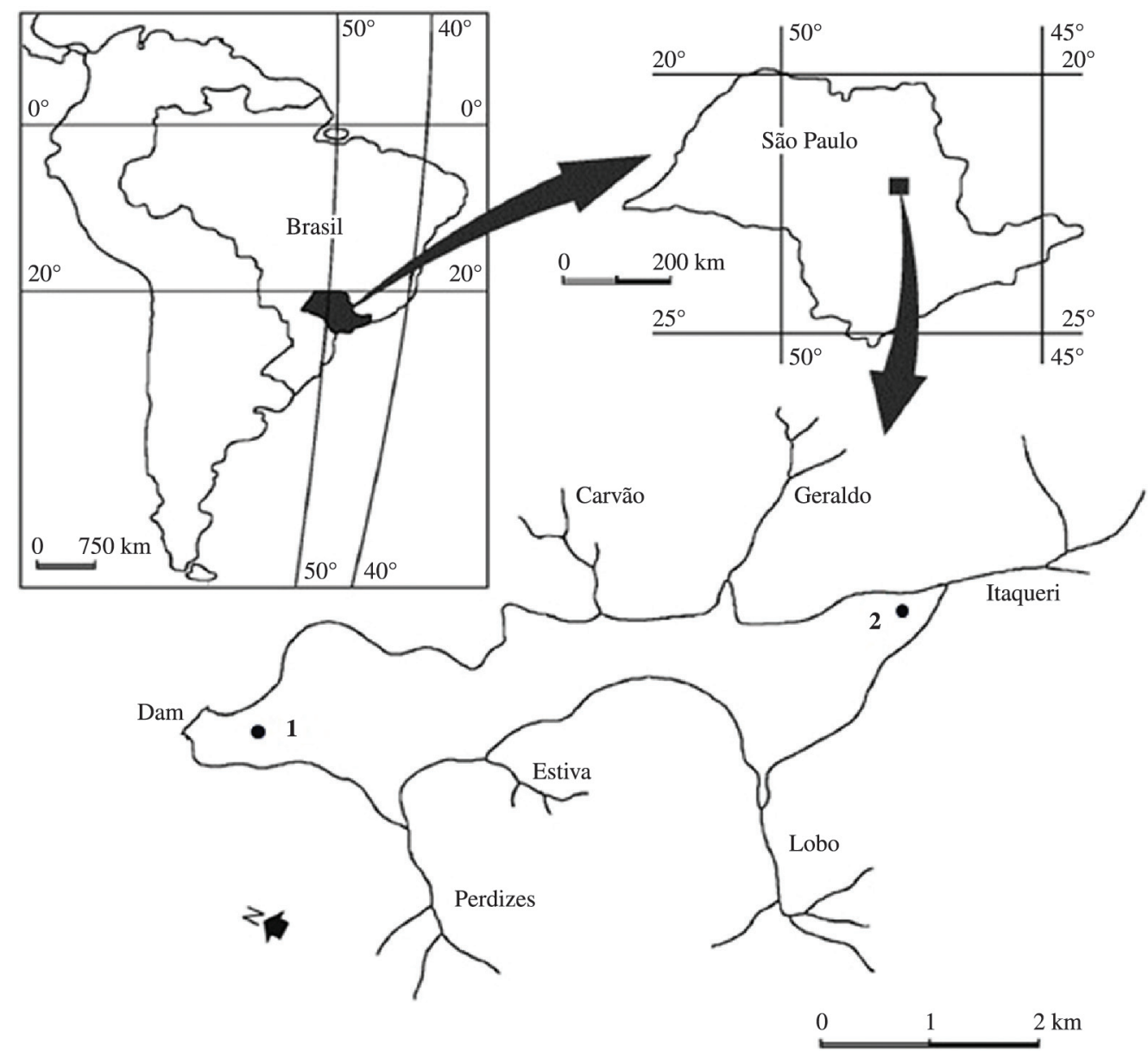

Figure 1. Location of the Lobo Reservoir and its main tributaries with the indication of the two sampling points (Modified from Tundisi et al., 2004). 
the water sub-surface $(0.5 \mathrm{~m})$, during a year, which included three surveys in the dry season (May, July and September 2010) and three in the rainy season (November 2010, January and March 2011). Collected water samples were used for environmental and microbial community analyses.

\subsection{Environmental and microbial community analyses}

The $\mathrm{pH}$, dissolved oxygen, temperature and water conductivity were measured in the field using a multisensor Horiba (U-10). With the water sampled, the concentration of suspended material was determined according to Teixeira et al. (1965) and the concentration of chlorophyll $a$ was measured according to Nusch (1980). Moreover, the concentration of total phosphorus and total nitrogen were quantified according to Valderrama (1981). The meteorological data such as precipitation were obtained from the Climatological Station of the Center for Water Resources and Applied Ecology (CRHEA-USP, São Carlos, Brazil).

To estimate the bacteria and nanoflagellates $(2-20 \mu \mathrm{m})$ density, water samples $(100 \mathrm{~mL})$ were fixed in the field with a neutral formalin solution (final concentration $2 \%$ ). In the laboratory, aliquots of these samples were stained with the fluorochrome 4',6'-diamidino-2-phenylindole (DAPI), according to Porter and Feig (1980) and filtered through $0.2 \mu \mathrm{m}$ pore size black polycarbonate membranes (Nuclepore ${ }^{\circledR}$ ) for bacteria and $0.8 \mu \mathrm{m}$ for nanoflagellates. For counting and measurement of bacteria and total nanoflagellates (TNF) it was used an epifluorescence microscope Olympus BHS-313, equipped with HBO 200 mercury lamp and filter set for UV light. For the autotrophic nanoflagellates (ANF), a filter set for blue light was used. The number of heterotrophic nanoflagellates (HNF) was estimated by the difference between the number of TNF and ANF. Based on the length/width ratio, bacterial cells were classified into the following morphotypes: coccus (ratio 1 to 1.25); coccobacillus (1.26 to 1.75), bacillus (1.76 to 5) and filament ( $>5)$. Other morphotypes, like vibrio, were also quantified. The HNF were classified according to their length, into three classes: Class I $(<5.0 \mu \mathrm{m})$; Class II (5 to $10 \mu \mathrm{m})$ and Class III $(>10 \mu \mathrm{m})$.

To estimate ciliates density, water samples $(200 \mathrm{~mL})$ were fixed in the field with mercuric chloride and stained with bromophenol blue at $0.04 \%$ (Pace and Orcutt Junior, 1981). At the laboratory, the flasks with the samples were left undisturbed for the organisms sedimentation. The supernatant liquid was discarded and the remaining concentrated material was counted in Sedgwick-Rafter chambers in an optical microscope. Protozoan taxonomic features were also analysed in counts from fixed samples. For protozoan identification, unfixed protozoan samples, concentrated in the field with a plankton net $(10 \mu \mathrm{m})$, were analysed within a maximum period of 6 hours after the sampling, using an optical microscope. The ciliates identification was based mainly on Dragesco and DragescoKernéis (1986), Foissner and Berger (1996), Foissner et al. (1991, 1992, 1994, 1995, 1999), Patterson (1996) and the ciliates identified were separated in groups according to the classification proposed by Lynn (2008). Considering the ecological importance of the protozoans food preferences for bacterivory experiments, the ciliates feeding habits were classified according to Foissner and Berger (1996).

\subsection{Bacterivory experiments}

The in situ grazing experiments were conducted with fluorescently labelled bacteria (FLB) of the Escherichia coli species stained with 5-(4, 6 dichlorotriazin-2-yl) aminofluorescein (DTAF) as described by Sherr et al. (1987). Two bottles containing $900 \mathrm{~mL}$ of water from the reservoir were used: one for flagellate and the other for ciliate bacterivory experiment. In these bottles, FLB was added at the proportion of $30 \%$ of the bacterioplanktonic density (no less than $1 \times 10^{6} \mathrm{~mL}^{-1}$ ) for flagellates and $5 \%$ of bacterioplanktonic density (no less than $1 \times 10^{5} \mathrm{~mL}^{-1}$ ) for ciliates. After adding FLB, the bottles were incubated at in situ temperature. Subsamples $(100 \mathrm{~mL})$ were taken at $0,5,10,20$ and 30 minutes of incubation and fixed with lugol alkaline solution $0.5 \%$, followed by buffered formalin with borax and cleared with sodium thiosulfate solution to 3\% (Sherr and Sherr, 1993). In the laboratory, $20 \mathrm{~mL}$ of each subsample was stained with 4',6'-diamidino2-phenylindole(DAPI), filtered on black polycarbonate membranes of $0.8 \mu \mathrm{m}$ of pore diameter and analysed in an epifluorescence microscope Olympus BHS-313 with filters for UV light to locate the protozoans, and filters for blue light, to count FLB in its interior (increase of 1250x).

The FLB uptake rate was calculated by regression of the linear portion of the curve of the average number of FLB per protozoan cell versus time. The specific ingestion rate (cells ind ${ }^{-1} \mathrm{~h}^{-1}$ ) was determined by multiplying the FLB uptake rate by the ratio of native bacterial density to FLB. To obtain the population ingestion rate (cells $\mathrm{mL}^{-1} \mathrm{~h}^{-1}$ ), the specific ingestion rate was multiplied by the protozoan density analysed (cells $\mathrm{mL}^{-1}$ ) (Sherr and Sherr, 1993). The total bacterivory rate by protozoans was determined as the sum of population ingestion rates of heterotrophic nanoflagellates and ciliates.

\subsection{Statistical analyses}

The Student's t-test was used to verify possible differences between the two sampling points and the Pearson correlation test was used to determine potential relationships among different variables. The Principal Component Analysis (PCA) was used as a method of ordination of the correlations among the environmental variables analysed, with the aim of indicating the relative significance of the predictive variables. All the statistical analyses were performed using the XLSTAT Pro 2008 software.

\section{Results}

\subsection{Environmental and microbial community analyses}

Environmental variables data analysed in the two points, during the studied period, are shown in Table 1. From the principal component analysis (PCA) (see Figure 2), 
Table 1. Environmental variable values analysed in the two sampling points during the studied period in the Lobo Reservoir. Precip (total precipitation); DO (dissolved oxygen); T (water temperature); Cond (conductivity); TSM (total suspended material); Chl (chlorophyll a); TN (total nitrogen); TP (total phosphorus).

\begin{tabular}{|c|c|c|c|c|c|c|c|c|c|c|}
\hline \multirow{2}{*}{ Months } & \multirow{2}{*}{ Points } & Precip & pH & DO & $\mathbf{T}$ & Cond & TSM & Chl & $\mathbf{T N}$ & $\mathbf{T P}$ \\
\hline & & $\mathbf{m m}$ & - & $\mathrm{mg} \mathrm{L}^{-1}$ & ${ }^{\circ} \mathbf{C}$ & $\mu \mathrm{S} \mathrm{\textrm {cm } ^ { - 1 }}$ & $\mathrm{mg} \mathrm{L}^{-1}$ & $\mu g L^{-1}$ & $\mu g L^{-1}$ & $\mu g L^{-1}$ \\
\hline \multirow[t]{2}{*}{ May 2010} & P1 & \multirow{2}{*}{24.1} & 6.6 & 8.1 & 20.0 & 16.8 & 1.8 & 13.9 & 119.0 & 20.0 \\
\hline & $\mathrm{P} 2$ & & 6.4 & 8.7 & 19.5 & 16.0 & 2.5 & 12.6 & 151.7 & 42.5 \\
\hline \multirow[t]{2}{*}{ July 2010} & $\mathrm{P} 1$ & \multirow{2}{*}{30.7} & 6.8 & 9.8 & 18.4 & 11.0 & 5.2 & 27.1 & 145.1 & 52.9 \\
\hline & $\mathrm{P} 2$ & & 6.5 & 9.4 & 19.1 & 11.0 & 5.3 & 18.4 & 124.9 & 64.4 \\
\hline \multirow{2}{*}{$\begin{array}{c}\text { September } \\
2010\end{array}$} & $\mathrm{P} 1$ & \multirow{2}{*}{54.8} & 5.7 & 8.7 & 22.0 & 10.0 & 8.8 & 26.6 & 110.6 & 30.1 \\
\hline & $\mathrm{P} 2$ & & 6.5 & 9.3 & 23.0 & 10.0 & 14.0 & 30.6 & 94.9 & 59.0 \\
\hline \multirow{2}{*}{$\begin{array}{c}\text { November } \\
2010\end{array}$} & $\mathrm{P} 1$ & \multirow{2}{*}{143.4} & 7.6 & 9.7 & 24.7 & 13.0 & 8.5 & 30.2 & 165.4 & 34.7 \\
\hline & $\mathrm{P} 2$ & & 7.0 & 9.5 & 25.4 & 12.0 & 10.0 & 32.7 & 183.0 & 47.7 \\
\hline \multirow[t]{2}{*}{ January 2011} & $\mathrm{P} 1$ & \multirow{2}{*}{543.8} & 5.7 & 6.6 & 26.9 & 11.0 & 7.0 & 9.3 & 100.8 & 28.5 \\
\hline & $\mathrm{P} 2$ & & 5.8 & 6.6 & 28.3 & 10.0 & 18.4 & 17.6 & 118.4 & 46.1 \\
\hline \multirow[t]{2}{*}{ March 2011} & $\mathrm{P} 1$ & \multirow{2}{*}{306.0} & 4.0 & 5.6 & 24.8 & 12.0 & 6.0 & 6.4 & 128.2 & 31.4 \\
\hline & P2 & & 5.3 & 5.3 & 26.0 & 10.0 & 14.0 & 10.4 & 77.3 & 34.3 \\
\hline
\end{tabular}

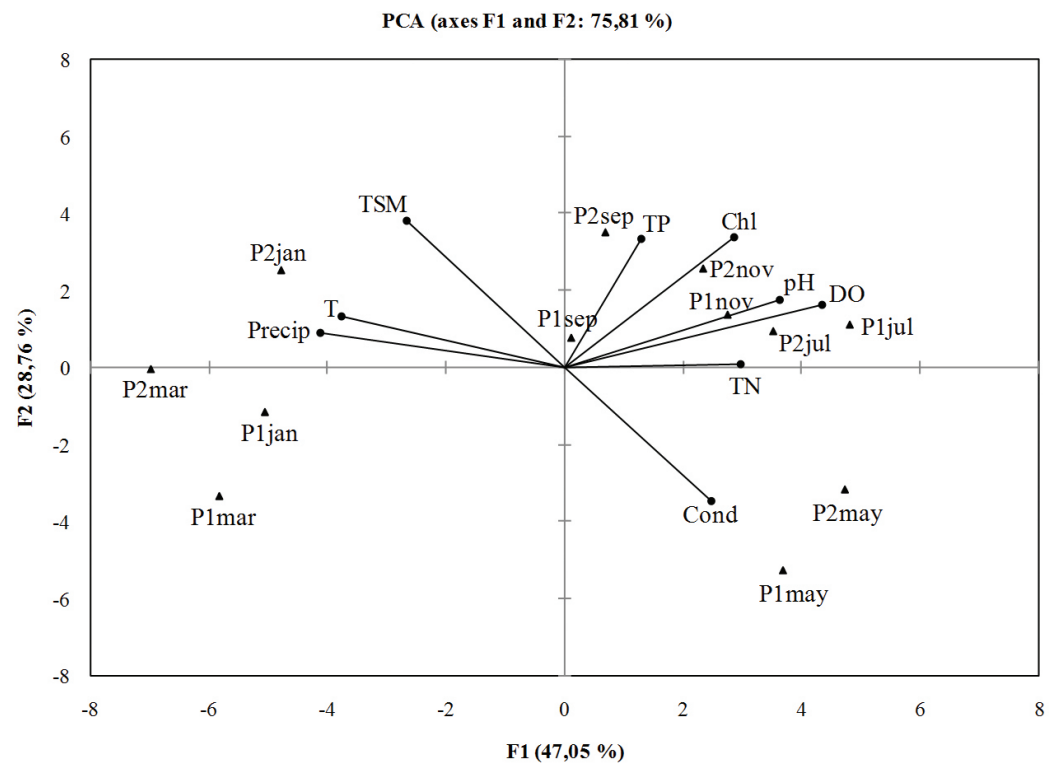

Figure 2. Ordination diagram of the Principal Component Analysis (PCA) with the limnological variables registered for the collection points during the studied period in the Lobo Reservoir. P1may and P2may (Point 1 and Point 2 in May 2010); P1jul and P2jul (Point 1 and Point 2 in July 2010); P1sep and P2sep (Point 1 and Point 2 in September 2010); P1nov and P2nov (Point 1 and Point 2 in November 2010); P1jan and P2jan (Point 1 and Point 2 in January 2011); P1mar and P2mar (Point 1 and Point 2 in March 2011); DO (dissolved oxygen); Chl (chlorophyll a); T (temperature); TSM (total suspended material); TP (total phosphorus); TN (total nitrogen); Precip (total precipitation); Cond (conductivity).

it was observed that the months of July, September and November 2010 were associated with dissolved oxygen, $\mathrm{pH}$, chlorophyll $a$, total nitrogen and total phosphorus because, in these months, these variables had their highest values. The months of January and March 2011 were associated with high values of total precipitation, temperature and concentration of total suspended material (TSM). The highest conductivity and the lowest total precipitation and TSM were obtained in May 2010.

The bacterial density ranged from $6.2 \times 10^{6}$ to $9.4 \times 10^{6}$ cells $\mathrm{mL}^{-1}$ (see Figure $3 \mathrm{a}$ ), with a mean value of $8.5 \times 10^{6}$ cells $\mathrm{mL}^{-1}$. In all months, the bacterial density was higher in P2 (except in July). The mean bacterial biovolumes were $0.19 \mu \mathrm{m}^{3}$ for coccobacilli, $0.15 \mu \mathrm{m}^{3}$ for cocci, $0.43 \mu \mathrm{m}^{3}$ for bacilli, $1.05 \mu \mathrm{m}^{3}$ for filaments and $0.39 \mu \mathrm{m}^{3}$ for vibrios, and these morphotypes represented, respectively, $41 \%$, $35 \%, 21 \%, 2 \%$ and $1 \%$ of total bacterioplankton. The coccobacilli dominated in all months, except for May in which the coccoid form prevailed. The mean density and biovolume of filaments were higher in November $\left(3.0 \times 10^{5}\right.$ cells $\mathrm{mL}^{-1}$ and $1.3 \mu \mathrm{m}^{3}$, respectively) and the mean density of filaments was lower in July $\left(1.1 \times 10^{5}\right.$ cells $\left.\mathrm{mL}^{-1}\right)$. 
The average density of heterotrophic nanoflagellates (HNF) was $1.3 \times 10^{3}$ cells $\mathrm{mL}^{-1}$, and the maximum $\left(2.7 \times 10^{3}\right.$ cells $\mathrm{mL}^{-1}$ ) occurred in $\mathrm{P} 2$ in November and the minimum in P1 in May $\left(0.8 \times 10^{3}\right.$ cells $\left.\mathrm{mL}^{-1}\right)$ (see Figure $\left.3 \mathrm{~b}\right)$. In all months, the HNF density was higher in P2 than in P1 (except in July). The HNF less than $5 \mu \mathrm{m}$ (class I) predominated numerically in the Lobo Reservoir (77.0\%), followed by class II $(17.8 \%)$.

The ciliate density ranged from 14.8 to 47.9 cells $\mathrm{mL}^{-1}$ (see Figure $3 \mathrm{c}$ ), with a mean of 24.6 cells $\mathrm{mL}^{-1}$. In all months sampled, the ciliate abundance was higher in P2 than in P1 (except in July). During the studied period,
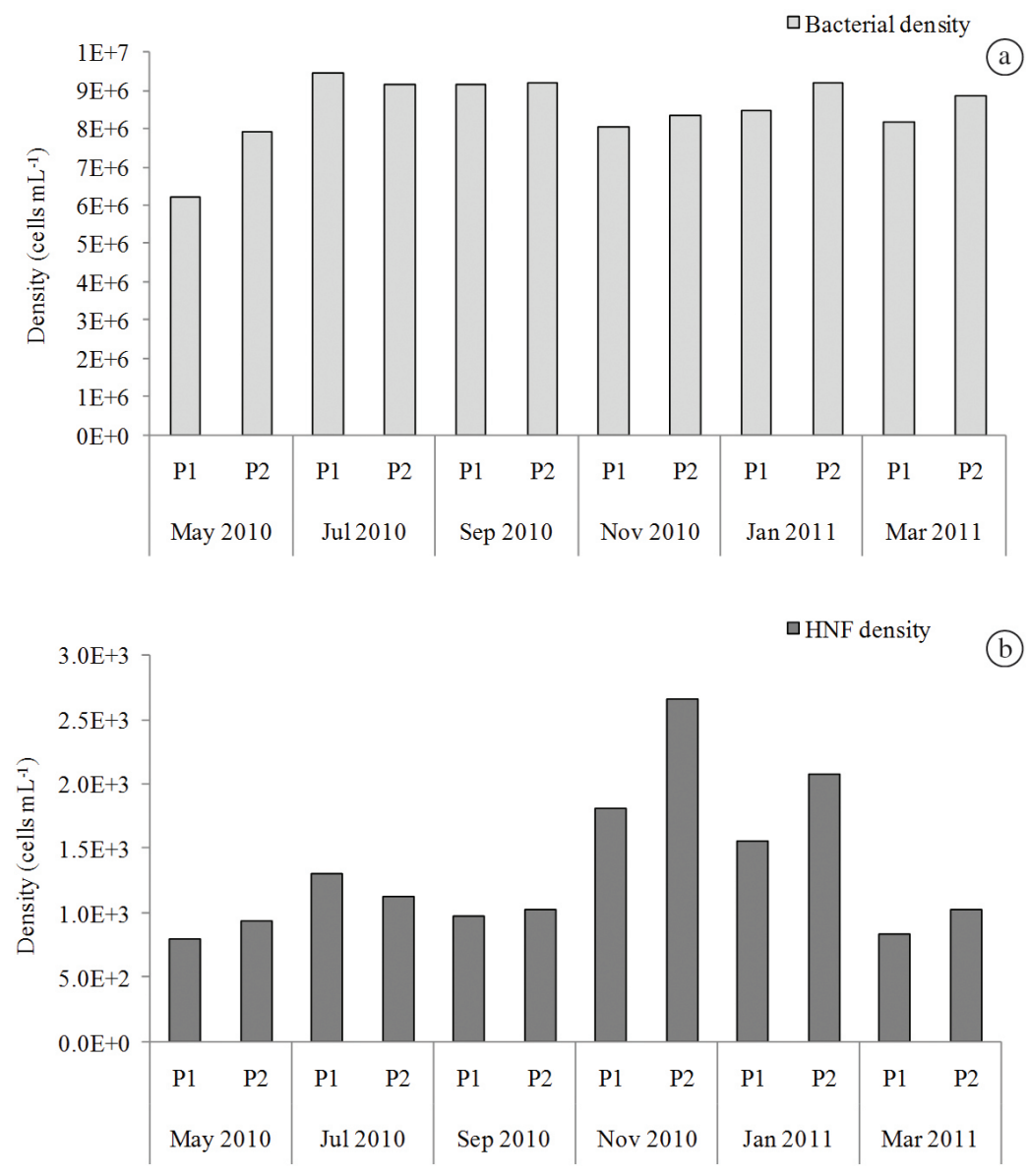

(c)

- Ciliates density

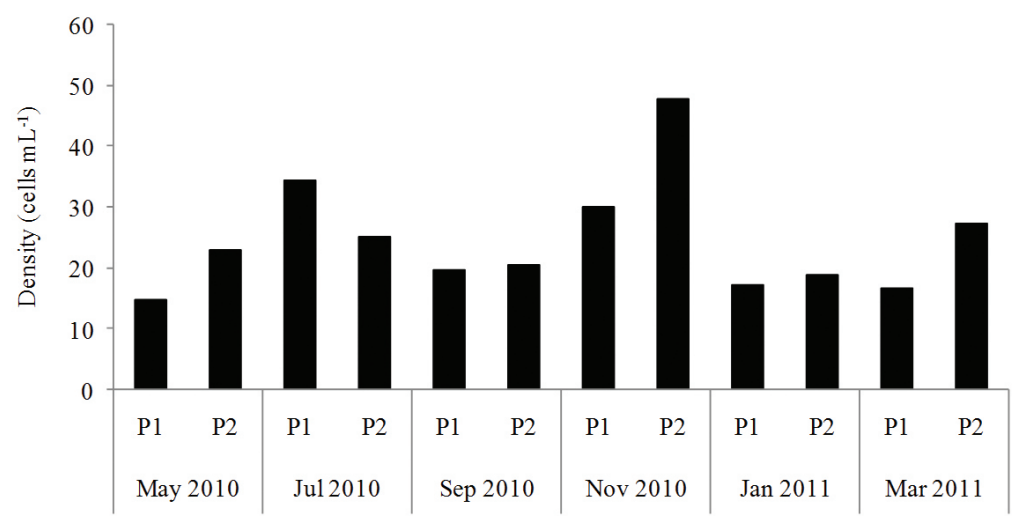

Figure 3. Density of the bacteria (a), heterotrophic nanoflagellates (b) and ciliates (c) in the two sampling points in the Lobo Reservoir during the studied period. HNF (heterotrophic nanoflagellates); P1 (Point 1); P2 (Point 2). 
a total of 32 ciliates taxa were identified in the Lobo Reservoir. The most abundant ciliates were Mesodinium pulex (Claparède and Lachmann, 1859) Stein, 1867 (16.7\%) and Halteria grandinella (Mueller, 1773) Dujardin, 1841 (13.5\%), followed by Thylacidium pituitosum Foissner, 1980 (12.0\%), Vorticella aquadulcis-complex (7.5\%) and Cyclidium glaucoma Mueller, 1773 (7.3\%). Regarding feeding habits, there was density predominance of ciliate bacterivorous/algivores (34.2\%), followed by omnivores (19.0\%) and bacterivorous (18.6\%).

Figure 4 shows, for the two sampling points, the seasonal variations of the relative density of the ciliates groups. The predominant groups in the Lobo Reservoir, in relation to annual mean density, were Spirotrichea (29.9\%) and Haptoria (19.2\%), followed by Scuticociliatia (17.1\%) and Peritrichia (13.3\%).

\subsection{Protozoan bacterivory}

The specific ingestion rates (SIR) ranged from 27.5 to 119.6 cells ind ${ }^{-1} \mathrm{~h}^{-1}$ (mean of 79.7 cells ind ${ }^{-1} \mathrm{~h}^{-1}$ ) for HNF and from 918.8 to 9887.6 cells ind $^{-1} \mathrm{~h}^{-1}$ (mean of 3313.3 cells ind $^{-1} \mathrm{~h}^{-1}$ ) for ciliates. The population ingestion rates (PIR) for HNF ranged from $2.2 \times 10^{4}$ to $3.1 \times 10^{5}$ cells $\mathrm{mL}^{-1} \mathrm{~h}^{-1}$ (mean of $1.1 \times 10^{5}$ cells $\mathrm{mL}^{-1} \mathrm{~h}^{-1}$ ) and for ciliates ranged from $1.4 \times 10^{4}$ to $1.9 \times 10^{5}$ cells $\mathrm{mL}^{-1} \mathrm{~h}^{-1}$ (mean of $7.8 \times 10^{4}$ cells $\mathrm{mL}^{-1} \mathrm{~h}^{-1}$ ).

The ingestion rates for both $\mathrm{HNF}$ and ciliates were statistically different between the P1 and P2 (Student's t-test). The mean, maximum and minimum values of the SIR and PIR for HNF and ciliates observed at each point during the studied period are presented in Table 2. For both HNF and ciliates, the lowest value of SIR and PIR occurred in May, 2010. For ciliates, the highest value of SIR and PIR occurred in January 2011, while for HNF, the highest value of SIR occurred in March 2011 and of PIR in November 2010 (as shown in Table 2). In general, for ciliates and $\mathrm{HNF}$, the average ingestion rates in $\mathrm{P} 2$ were about twice higher than in P1.

During the studied period, large variations were observed in the total bacterivory rate (TBR) by protozoans (nanoflagellates + ciliates) (see Figure 5). The lowest TBR was observed in P1 in May $\left(3.6 \times 10^{4}\right.$ cells $\left.\mathrm{mL}^{-1} \mathrm{~h}^{-1}\right)$, while the highest values were observed in $\mathrm{P} 2$ in November $\left(3.8 \times 10^{5}\right.$ cells $\left.\mathrm{mL}^{-1} \mathrm{~h}^{-1}\right)$ and in January $\left(3.6 \times 10^{5}\right.$ cells $\mathrm{mL}^{-1} \mathrm{~h}^{-1}$ ). In all months, the TBR was higher in P2 than in P1 and in July 2010, the values were almost equal in the two points (see Figure 5).

In $\mathrm{P} 1$, the bacterivory by HNF was more important than by ciliates because in every month the PIR by HNF

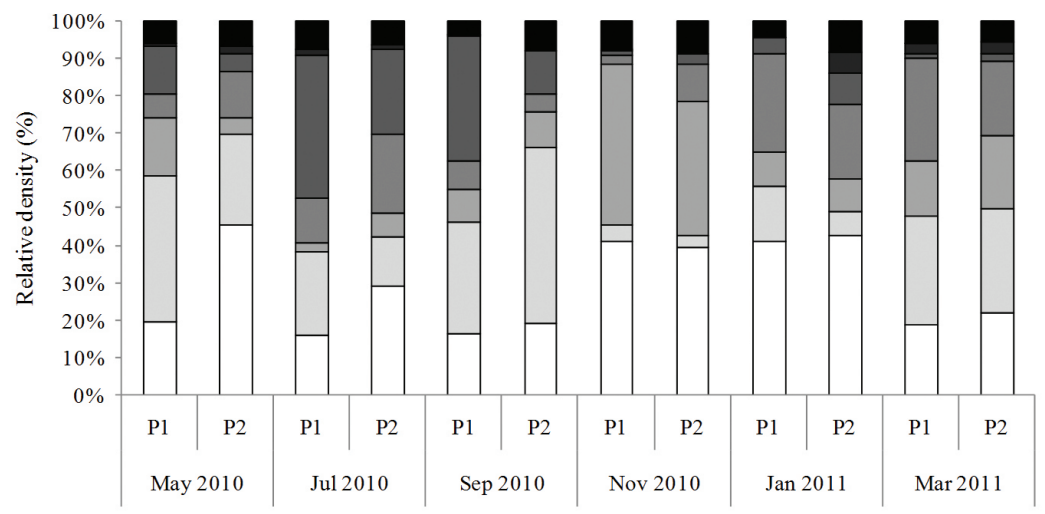

$\square$ Spirotrichea $\square$ Haptoria $\square$ Scuticociliatia $\square$ Peritrichia $\square$ Colpodea $\square$ Peniculia $\square$ Others

Figure 4. Relative density of the ciliates taxonomical groups in the two sampling points in the Lobo Reservoir during the studied period. P1 (Point 1); P2 (Point 2).

Table 2. Mean, minimum (min) and maximum (max) values of the specific ingestion rates (SIR) and population ingestion rates (PIR) of heterotrophic nanoflagellates (HNF) and ciliates in the two sampling points analysed in the Lobo Reservoir during the studied period (May 2010 to March 2011).

\begin{tabular}{|c|c|c|c|c|c|}
\hline & & HNF SIR & Ciliates SIR & HNF PIR & Ciliates PIR \\
\hline & & $\left(\right.$ cells ind $\left.{ }^{-1} h^{-1}\right)$ & $\left(\right.$ cells ind $\left.{ }^{-1} h^{-1}\right)$ & $\left(10^{4}\right.$ cells $\left.\mathrm{mL}^{-1} \mathrm{~h}^{-1}\right)$ & $\left(10^{4}\right.$ cells $\left.\mathrm{mL}^{-1} \mathrm{~h}^{-1}\right)$ \\
\hline \multirow[t]{3}{*}{$\mathrm{P} 1$} & mean & 59.6 & 2390.1 & 7.7 & 5.5 \\
\hline & $\min$ & 27.5 (May) & 918.8 (May) & 2.2 (May) & 1.4 (May) \\
\hline & $\max$ & 76.8 (Jan) & 4503.8 (Jan) & 13.4 (Nov) & 14.7 (July) \\
\hline \multirow[t]{3}{*}{$\mathrm{P} 2$} & mean & 99.9 & 4236.6 & 14.9 & 10.2 \\
\hline & $\min$ & 74.7 (May) & 1334.3 (Sept) & 7.0 (May) & 2.7 (Sept) \\
\hline & $\max$ & 119.6 (Mar) & 9887.6 (Jan) & 30.5 (Nov) & $18.7(\mathrm{Jan})$ \\
\hline
\end{tabular}




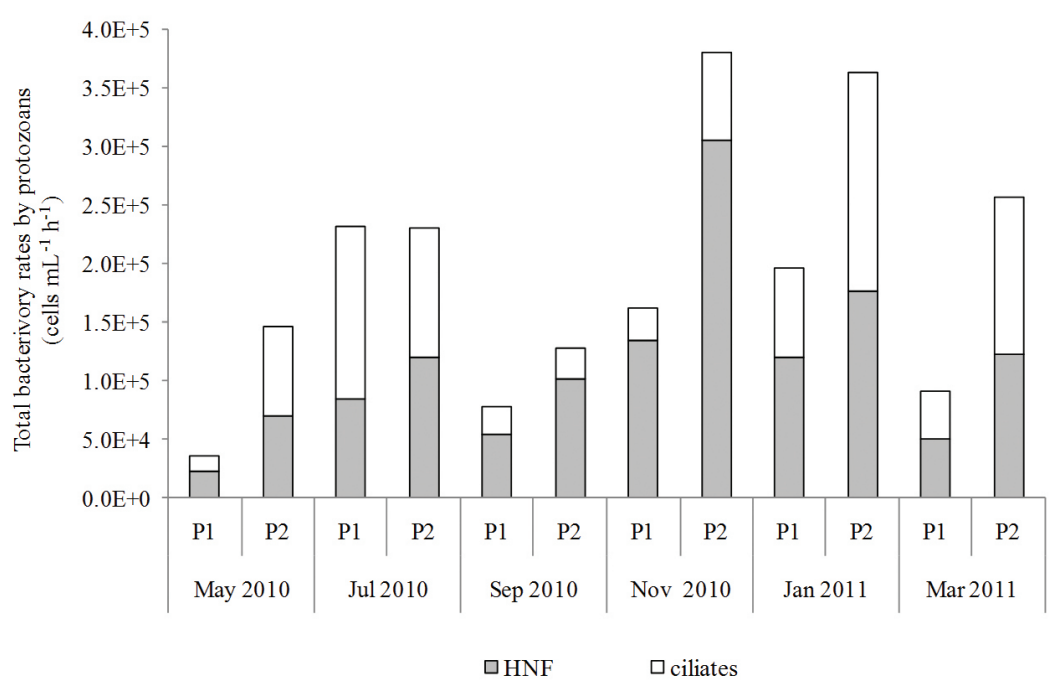

Figure 5. Total bacterivory rates by protozoans (population ingestion rates of nanoflagellates + ciliates) in the two sampling points in the Lobo Reservoir during the studied period. HNF (heterotrophic nanoflagellates); P1 (Point 1); P2 (Point 2).

was higher than by ciliates (except July 2010). In P2, the impact of these two populations was almost equal because, in most of the months, the PIR for HNF and ciliates were very close (May 2010, July 2010, January 2011, March 2011), and only in September and November 2010 the bacterivory impact by HNF was higher (see Figure 5). However, considering all months and the two points analysed, in the Lobo Reservoir the impact of the HNF bacterivory (60\%) was higher than by the ciliates $(40 \%)$.

\section{Discussion}

In the Lobo Reservoir, bacterial densities were similar to those frequently observed in freshwater environments according to Pedrós-Alió (1989). The predominant bacterial morphotypes in this study (coccobacilli and cocci) were the same reported in Racy et al. (2005) for this reservoir. For the heterotrophic nanoflagellates (HNF) the mean density $\left(1.3 \times 10^{3}\right.$ cells $\left.\mathrm{mL}^{-1}\right)$ was within the range of variation of $10^{2}$ to $10^{6}$ cells $\mathrm{mL}^{-1}$ found by Berninger et al. (1991) for freshwater environments. The mean ciliate density (24.6 cells $\mathrm{mL}^{-1}$ ) obtained in this study was higher than that found by Barbieri and Godinho (1989) (mean of 1.97 cells $\mathrm{mL}^{-1}$ ) for the same reservoir. We believed that the increase of ciliates over the years may be related to the eutrophication process of the reservoir.

The specific ingestion rates (SIR) observed for ciliates were higher than the ranges estimated by Comte et al. (2006) ( 2 to 612 cells ind $\left.{ }^{-1} \mathrm{~h}^{-1}\right)$ and those by Jezbera et al. (2003) (46 to 1808 cells ind ${ }^{-1} \mathrm{~h}^{-1}$ ). The SIR observed for HNF were within the range found by various authors (e.g. Weisse, 1990; Boenigk and Arndt, 2000; Boenigk et al., 2002; Shannon et al., 2007). The SIR for ciliates were higher than for HNF in all months and points, which can be explained by the morphology of each group. The ciliates are generally larger than nanoflagellates and have different modes of capture and food ingestion. In general, the protozoan ciliates have their food apparatus surrounded by cilia on the cell surface or in a cavity on the cell surface (Lee and Kugrens, 1992), which favours the uptake of a greater number of bacteria when compared to the flagellates that do not have cilia. Likewise, the constant water flow through the cilia favours the obtaining and entry of a large number of food particles in the cells of these protozoans (Fenchel, 1980).

Despite the fact that the specific ingestion rate (SIR) for ciliates is higher than for HNF, the population ingestion rates (PIR) for HNF were higher than for ciliates in the majority of the months studied (see Figure 5). The highest PIR for flagellates are explained by the higher densities of these organisms when compared to ciliate densities in the reservoir (see Figure 3). Nevertheless, in some months (mainly in P2), the SIR for ciliates was so high (e.g. P2 in January), that even with high HNF densities, the PIR for HNF was close to the PIR for ciliates. In some situations, the PIR for HNF was lower than that for ciliates (e.g. P1 in July).

For both ciliates and HNF, the specific ingestion rates were always higher in P2 than in P1. We believed that this is probably due to the more accelerated metabolism of the protozoans in $\mathrm{P} 2$ due to higher water temperatures. According to Sherr et al. (1988) higher temperatures favour the consumption of bacteria, since bacterivory is directly dependent on temperature. During this study, it was observed that the time of linear uptake for HNF and ciliates in P2 (20min for HNF and 10min for ciliates) was lower than in P1 (30min for HNF and 20min for ciliates), which is an indication of the more accelerated metabolism of protozoans in P2. Furthermore, it should also be noted that P2 has a higher prey availability (higher bacteria density) than P1. Thus, it is expected that the greater 
the prey supply for protozoans in the environment, the higher are their ingestion rates, which was supported by the positive correlation between the bacterial density with PIR for HNF $(r=0,574, p<0.05)$ and with the PIR for ciliates $(\mathrm{r}=0.599, \mathrm{p}<0.05)$.

The highest ciliate ingestion rates were observed in January 2011, due to the fact that the ciliated population were numerically dominated by the group Spirotrichea (mainly Halteria grandinella), composed of small bacterivorous ciliates (usually $<30 \mu \mathrm{m}$ ) and by the Peritrichia group (mainly represented by Campanella umbellaria and Vorticella aquadulcis-complex), composed by efficient bacterial filter feeders. Šimek et al. (1995) obtained high specific clearance rates for the Halteria grandinella and Vorticella aquadulcis-complex, confirming these species as highly efficient filter feeders. The Spirotrichea, Peritrichia, Haptoria and Scuticociliatia were the main bacterivorous groups in the Lobo Reservoir. However, based on previous studies (e.g. Šimek et al., 1995, 2000; Jezbera et al., 2003), the most important pelagic bacterivorous ciliates are the oligotrichids (Spirotrichea), peritrichids (Peritrichia) and scuticociliatids (Scuticociliatia).

In general, the main bacterial consumers in the Lobo Reservoir were the HNF smaller than $5 \mu \mathrm{m}$ (class I) due to their high density when compared to the larger HNF (classes II and III) and ciliates. According to Sherr and Sherr (1991), the HNF smaller than $5 \mu \mathrm{m}$ are the dominant class composed mainly by bacterivorous organisms.

Considering the total bacterivory by protozoans (HNF + ciliates) in the Lobo Reservoir, the HNF caused a greater predation impact (60\%) than the ciliates $(40 \%)$. In general, HNF have been reported as the main bacterial consumers in most aquatic systems (Boenigk et al., 2002; Gasol et al., 2002; Ichinotsuka et al., 2006). However, in some environments, the ciliates may be the most important consumers of bacterioplankton (Zingel et al., 2007).

The ciliates also contributed significantly to the bacterivory in the Lobo Reservoir, mainly in P2 (mesoeutrophic), in which they presented high densities and ingestion rates when compared to the P1 (oligo-mesotrophic). According to some authors, the relative importance of the bacterivory for ciliates seems to increase along the trophic gradient of mesotrophic to eutrophic (e.g. Jezbera et al., 2003), as observed in this study. In general, there is growing evidences that ciliates contribute significantly to the grazing on bacteria and, therefore, should not be ignored in the investigation of pelagic food webs.

In the Lobo Reservoir, bacterial predation by protozoans was not only a controlling factor, but also a modifier of the bacteria community, because predation by HNF induced changes in the bacterioplanktonic community structure, such as the increase in the size and proportion of bacterial filaments. The formation of filaments by bacteria is considered a protection mechanism against the predation by HNF because filamentous bacteria have a selective advantage due to the decrease in the ingestion efficiency by flagellates with increasing bacterial length (Pernthaler, 2005). In the Lobo Reservoir, the highest concentrations of filaments were observed in November 2010, when the highest HNF densities and high predation impact by HNF were found $(81.5 \%$ of total). However, although the total bacterivory rate was also high in July, lower concentrations of filaments were observed because in this month the main bacterial consumers were the ciliates (predation impact by ciliates of $55.9 \%$ of total). Thus, the possible bacterial community strategy of develop grazing-resistant forms (filaments) against the HNF predation in July was not so efficient, because it did not avoided ciliate grazing.

Regarding the main controlling forces of bacterial abundance in the Lobo Reservoir, the bottom-up control was more important in the dry season (May, July and September 2010) and the top-down control more important in the rainy one (November 2010, January and March 2011). In May, the lowest ingestion rates by flagellates and ciliates were observed and, despite this, the bacterial densities did not increase in response because of the nutritional poverty of the system (higher water column stability and lower allochthonous nutrient input), demonstrating that the control of bacteria by nutrient availability (bottom-up) was more important in this month. The highest bacterial densities occurred in July, when the reservoir had high concentrations of nutrients (mainly phosphorus). In this month, even with a high abundance of ciliates and HNF, as well as high bacterivory rates, the bacteria density did not decrease, suggesting that predation was not of great importance in the regulation of bacterial abundance in July. In September, the high bacterial densities can be explained by the high nutrient availability and the low ingestion rates by flagellates and ciliates due to low densities of these populations. During the rainy season (November 2010, January and March 2011), although the reservoir presents high nutrient availability (allochthonous nutrient input and by sediment resuspension) and bacteria entry from soil and sediment due to precipitation, the bacterial density was lower than in July and September (dry season). However, during the rainy season high bacterivory rates were observed, mainly by HNF in November and by ciliates and HNF in January and March, showing that the predation control (top-down) on bacteria was more important in these months.

According to Koton-Czarnecka and Chróst (2002), the top-down control on bacterial community is more important in eutrophic ecosystems, while the bottom-up control is more important in oligotrophic systems. However, Gasol et al. (2002), highlighted the simultaneous top-down and bottom-up control, since the changes in the bacterial community composition, as, for example, the increase in bacterial size in order to avoid predation by flagellates, is dependent on the nutrients availability in the system. In the present study, the relative importance of the bottom-up and top-down control changed seasonally, as discussed earlier, so, these two forces are equally important to the bacterial abundance regulation in the Lobo Reservoir in an annual basis.

In summary, the present study revealed that the HNF (mainly the HNF smaller than $5 \mu \mathrm{m}$ ) caused the greatest 
grazing impact on the bacterial community of the Lobo Reservoir. However, the ciliates contributed significantly to the bacterivory, mainly in P2, due to their high densities and ingestion rates. The bottom-up (most important in the dry season) and top-down control (most important in the wet season), are both important in an annual basis, to the bacterial abundance regulation in this reservoir. In general, the determination of grazing rates was important not only to evaluate the role of bacteria and bacterivorous protozoans in this aquatic food chain, but also to evaluate the significance of the top-down and/or bottom-up control as regulating mechanisms of the bacterial community.

\section{Acknowledgements}

We thank Mrs. Darci C.D. Javaroti for the laboratory assistance and the state of São Paulo Research Foundation - FAPESP (process $n^{\circ} 09 / 12435-6$ ) for the scholarship granted to the first author.

\section{References}

APPLE, JK., SMITH, EM. and BOYD, TJ., 2008. Temperature, Salinity, Nutrients, and the Covariation of Bacterial Production and Chlorophyll-a in Estuarine Ecosystems. Journal of Coastal Research, vol. 55, p. 59-75. http://dx.doi.org/10.2112/SI55-005.1.

BARBIERI, SM. and GODINHO, MJL., 1989. Planktonic protozoa in a tropical reservoir: temporal variation in abundance and composition. Revue d'Hydrobiologie Tropicale, vol. 22, p. 275-285.

BELL, T., BONSALL, MB., BUCKLING, A., WHITELEY, AS., GOODALL, T. and GRIFFITHS, RI., 2010. Protists have divergent effects on bacterial diversity along a productivity gradient. Biology Letters, vol. 6, no. 5, p. 639-642. http://dx.doi. org/10.1098/rsbl.2010.0027. PMid:20219744

BERNINGER, UG., FINLAY, BJ. and KUUPPO-LEINIKKI, P., 1991. Protozoan control of bacterial abundances in freshwaters. Limnology and Oceanography, vol. 36, no. 1, p. 139-147. http:// dx.doi.org/10.4319/1o.1991.36.1.0139.

BOENIGK, J. and ARNDT, H., 2000. Particle handling during interception feeding by four species of heterotrophic nanoflagellates. The Journal of Eukaryotic Microbiology, vol. 47, no. 4, p. 350358. http://dx.doi.org/10.1111/j.1550-7408.2000.tb00060.x. PMid:11140448

BOENIGK, J., MATZ, C., JÜRGENS, K. and ARNDT, H., 2002. Food concentration- dependent regulation of food selectivity of interception-feeding bacterivorous nanoflagellates. Aquatic Microbial Ecology, vol. 27, p. 195-202. http://dx.doi.org/10.3354/ ame027195.

COMTE, J., JACQUET, S., VIBOUD, S., FONTVIEILLE, D., MILLERY, A., PAOLINI, G. and DOMAIZON, I., 2006. Microbial community structure and dynamics in the largest natural French lake (Lake Bourget). Microbial Ecology, vol. 52, no. 1, p. 72-89. http://dx.doi.org/10.1007/s00248-004-0230-4. PMid:16733620

CORNO, G., CARAVATI, E., CALLIERI, C. and BERTONI, R., 2008. Effects of predation pressure on bacterial abundance, diversity, and size-structure distribution in an oligotrophic system. Journal of Limnology, vol. 67, no. 2, p. 107-119. http://dx.doi. org/10.4081/jlimnol.2008.107.
DRAGESCO, J. and DRAGESCO-KERNÉIS, A., 1986. Ciliés libres de l'Afrique intertropicale: introduction a La connaissance et à l'étude des ciliés. Paris: Éditions de l'Orstom. 559 p.

FENCHEL, T., 1980. Suspension feeding in ciliated protozoa: Functional response and particle size selection. Microbial Ecology, vol. 6, no. 1, p. 1-11. http://dx.doi.org/10.1007/BF02020370. PMid:24226830

FOISSNER, W. and BERGER, H., 1996. A user-friendly guide to the ciliates (Protozoa, Ciliophora) commonly used by hydrobiologists as bioindicators in rivers, lakes and waste waters with notes on their ecology. Freshwater Biology, vol. 35, p. 375-482.

FOISSNER, W., BLATTERER, H., BERGER, H. and KOHMANN, F., 1991. Taxonomische und ökologische Revision der Ciliaten des Saprobiensystems. Band I. Cyrtophorida, Oligotrichida, Hypotrichia, Colpodea.Munich: Informationsberichte des Bayer. Landesamtes für Wasserwirtschaft, Heft 1/91. 478 p.

FOISSNER, W., BERGER, H. and KOHMANN, F., 1992. Taxonomische und ökologische Revision der Ciliaten des Saprobiensystems. Band II. Peritrichia, Heterotrichida, Odontostomatida.Munich: Informationsberichte des Bayer. Landesamtes für Wasserwirtschaft, Heft 5/92. 502 p.

FOISSNER, W., BERGER, H. and KOHMANN, F., 1994. Taxonomische und ökologische Revision der Ciliaten des Saprobiensystems. Band III. Hymenostomata, Prostomatida, Nassulida.Munich: Informationsberichte des Bayer. Landesamtes für Wasserwirtschaft, Heft 1/94. 548 p.

FOISSNER, W., BERGER, H., BLATTERER, H. and KOHMANN, F., 1995. Taxonomische und ökologische revision der ciliaten des saprobiensystems - Band IV: Gymnostomates, Loxodes, Suctoria. Munich: Informationsberichte des Bayer. Landesamtes für Wasserwirtschaft, Heft 1/95. 540 p.

FOISSNER, W., BERGER, H. and SCHAUMBURG, J., 1999. Identification and ecology of limnetic plankton ciliates. Munich: Bavarian State Office for Water Management. 793 p.

GASOL, JM., PEDRÓS-ALIÓ, C. and VAQUÉ, D., 2002. Regulation of bacterial assemblages in oligotrophic plankton systems: results from experimental and empirical approaches. Antonie van Leeuwenhoek, vol. 81, no. 1-4, p. 435-452. http:// dx.doi.org/10.1023/A:1020578418898. PMid:12448741

ICHINOTSUKA, D., UENO, H. and NAKANO, S., 2006. Relative importance of nanoflagellates and ciliates as consumers of bacteria in a coastal sea area dominated by oligotrichous Strombidium and Strobilidium. Aquatic Microbial Ecology, vol. 42, p. 139-147. http://dx.doi.org/10.3354/ame042139.

JEZBERA, J., NEDOMA, J. and ŠIMEK, K., 2003. Longitudinal changes in protistan bacterivory and bacterial production in two canyon-shaped reservoirs of different trophic status. Hydrobiologia, vol. 504, no. 1-3, p. 115-130. http://dx.doi. org/10.1023/B:HYDR.0000008502.31554.ef.

KOTON-CZARNECKA, M. and CHRÓST, RJ., 2002. Measurement of Protozoan Grazing on Bacteria by Means of [3H-thymidine] - Labeled Natural Assemblages of Lake Bacteria. Journal of Environmental Studies, vol. 11, p. 385-393.

LEE, RE. and KUGRENS, P., 1992. Relationship between the flagellates and the ciliates. Microbiology and Molecular Biology Reviews, vol. 56, no. 4, p. 529-542. PMid:1480107.

LYNN, DH., 2008. The ciliated Protozoa: characterization, classification, and guide to the literature. 3rd ed. New York: Springer. $605 \mathrm{p}$. 
MOTEGI, C., NAGATA, T., MIKI, T., WEINBAUER, MG., LEGENDRE, L. and RASSOULZADEGAN, F., 2009. Viral control of bacterial growth efficiency in marine pelagic environments. Limnology and Oceanography, vol. 54, no. 6, p. 1901-1910. http://dx.doi.org/10.4319/lo.2009.54.6.1901.

MOTHEO, D.F., 2005. Estudo limnológico na Represa Carlos Botelho (Itirapina/Brotas - SP): uma reavaliação comparativa do sistema Lobo-Broa. São Carlos: CRHEA/EESC/USP. Dissertação de Mestrado.

NUSCH, EA., 1980. Comparasion of diferent methods for Clorophyll-a and phaeopigments determination. Archiv fuer Hydrobiologie, vol. 14, p. 14-36.

PACE, ML. and ORCUTT JUNIOR, JD, 1981. The relative importance of protozoans, rotifers and crustaceans in a freshwater zooplankton community. Limnology and Oceanography, vol. 26, no. 5, p. 822-830. http://dx.doi.org/10.4319/lo.1981.26.5.0822.

PATTERSON, DJ., 1996. Free-living freshwater protozoa: a colour guide. New York: John Wiley \& Sons. 223 p.

PEDRÓS-ALIÓ, C., 1989. Toward an autecology of bacterioplankton. In SOMMER, U. Plankton ecology: Succession in plankton communities. Berlin: Springer-Verlag. p. 297-336.

PERNTHALER, J., 2005. Predation on prokaryotes in the water column and its ecological implications. Nature Reviews. Microbiology, vol. 3, no. 7, p. 537-546. http://dx.doi.org/10.1038/ nrmicro1180. PMid:15953930

PINHASSI, J., GÓMEZ-CONSARNAU, L., ALONSO-SÁEZ, L., SALA, MM., VIDAL, M., PEDRÓS-ALIÓ, C. and GASOL, JM., 2006. Seasonal changes in bacterioplankton nutrient limitation and heir effects on bacterial community composition in the NW Mediterranean Sea. Aquatic Microbial Ecology, vol. 44, p. 241252. http://dx.doi.org/10.3354/ame044241.

PORTER, KG. and FEIG, YS., 1980. The use of DAPI for identifying and counting aquatic microflora. Limnology and Oceanography, vol. 25, no. 5, p. 943-948. http://dx.doi.org/10.4319/ 1o.1980.25.5.0943.

RACY, F., GODINHO, MJL., REGALI-SELEGHIM, MH., BOSSOLAN, NRS., FERRARI, AC. and LUCCA, JV., 2005. Assessment of the applicability of morphological and size diversity indices to bacterial populations of reservoirs in different trophic states. Acta Limnologica Brasiliensia, vol. 17, p. 395-408.

SHANNON, SP., CHRZANOWSKI, TH. and GROVER, JP., 2007. Prey food quality affects flagellate ingestion rates. Microbial Ecology, vol. 53, no. 1, p. 66-73. http://dx.doi.org/10.1007/ s00248-006-9140-y. PMid:17186152

SHERR, BF. and SHERR, EB., 1991. Proportional distribution of total numbers, biovolume and bacterivory among size classes of 2-20 $\mu \mathrm{m}$ nonpigmented marine flagellate. Marine Microbial Food Webs, vol. 5, p. 227-237.

SHERR, EB. and SHERR, BF., 1993. Protistan grazing rates via uptake of fluorescently labeled prey. In KEMP, P., SHERR, BF., SHERR, EB. and COLE, J. (Eds.). Handbook of methods in aquatic microbial ecology. London: Lewis Publishers. p. 695-702.

SHERR, BF., SHERR, EB. and FALLON, RD., 1987. Use of monodispersed, fluorescently labeled bacteria to estimate in situ protozoan bacterivory. Applied and Environmental Microbiology, vol. 53, no. 5, p. 958-965. PMid:16347355.

SHERR, BF., SHERR, EB. and RASSOULZADEGAN, F., 1988. Rates of digestion of bacteria by marine phagotrophic protozoa: temperature dependence. Applied and Environmental Microbiology, vol. 54, no. 5, p. 1091-1095. PMid:16347623.

ŠIMEK, K., BOBKOVÁ, J., MACEK, M., NEDOMA, J. and PSENNER, R., 1995. Ciliate grazing on picoplankton in a eutrophic reservoir during the summer phytoplankton maximum: a study at the species and community level. Limnology and Oceanography, vol. 40, no. 6, p. 1077-1090. http://dx.doi. org/10.4319/lo.1995.40.6.1077.

ŠIMEK, K., JÜRGENS, K., NEDOMA, J., COMERMA, M. and ARMENGOL, J., 2000. Ecological role and bacterial grazing of Halteria spp.: small freshwater oligotrichs as dominant pelagic ciliate bacterivores. Aquatic Microbial Ecology, vol. 22, p. 43-56. http://dx.doi.org/10.3354/ame022043.

TEIXEIRA, C., TUNDISI, JG. and KUTNER, MB., 1965. Plankton studies in mangrove environmental. II. The standing stock and some ecological factors. Boletim do Instituto Oceanográfico, vol. 24, p. 23-41.

TUNDISI, JG., MATSUMURA-TUNDISI, T., ARANTES JÚNIOR, JD., TUNDISI, JEM., MANZINI, NF. and DUCROT, R., 2004. The response of Carlos Botelho (Lobo, Broa) Reservoir to the passage of cold fronts as reflected by physical, chemical, and biological variables. Revista Brasileira de Biologia = Brazilian Journal of Biology, vol. 64, no. 1, p. 177-186. http://dx.doi.org/10.1590/ S1519-69842004000100020. PMid:15195377

VALDERRAMA, JC., 1981. The simultaneous analysis of total nitrogen and total phosphorus in natural waters. Marine Chemistry, vol. 10, no. 2, p. 109-122. http://dx.doi.org/10.1016/03044203(81)90027-X.

WEINBAUER, MG., HORNÁK, K., JEZBERA, J., NEDOMA, J., DOLAN, JR. and ŠIMEK, K., 2007. Synergistic and antagonistic effects of viral lysis and protistan grazing on bacterial biomass, production and diversity. Environmental Microbiology, vol. 9, no. 3, p. 777-788. http://dx.doi.org/10.1111/j.1462-2920.2006.01200.x. PMid: 17298376

WEISSE, T., 1990. Trophic interactions among heterotrophic microplankton, nanoplankton, and bacteria in Lake Constance. Hydrobiologia, vol. 191, no. 1, p. 111-122. http://dx.doi.org/10.1007/ BF00026045.

WRIGHT, RT., 1988. A model for short-term control of the bacterioplankton by substrate and grazing. Hydrobiologia, vol. 159, no. 1, p. 111-117. http://dx.doi.org/10.1007/BF00007372.

ZINGEL, P., AGASILD, H., NÕGES, T. and KISAND, V., 2007. Ciliates are the dominant grazers on pico- and nanoplankton in a shallow, naturally highly eutrophic lake. Microbial Ecology, vol. 53, no. 1, p. 134-142. http://dx.doi.org/10.1007/s00248-0069155-4. PMid: 17186145

ZÖLLNER, E., HOPPE, H-G., SOMMER, U. and JÜRGENS, K., 2009. Effect of zooplankton-mediated trophic cascades on marine microbial food web components (bacteria, nanoflagellates, ciliates). Limnology and Oceanography, vol. 54, no. 1, p. 262-275. http://dx.doi.org/10.4319/1o.2009.54.1.0262. 